\title{
【特 集：新しい資源循環型社会の動向（日欧比較を中心に）】
}

\section{使用済み自動車リサイクル制度の日本と EU の比較}

\author{
今 田 俊 史 *
}

【要 旨】 日欧に扔いて, 使用済み自動車の処理に対する責任と役割を, ユーザ, 処理インフラ業者, 行政，製造業者 4 者が担う新たな政策を織り込んだ制度化の動きとなった。日本，欧州とも社会問題化 した原因の根幹は同じであるが，その対応のアプローチは異なる結果となった。日本は逆有償に至る要 因であった ASR の引き取りをメーカ責任とし，欧州は逆有償となった使用済み自動車そのものを引き 取ることをメーカ責任とした。いずれもそのコストを直接もしくは，間接的にユーザが負担をし，処理 はメーカが契約を行ったインフラへ委託を行う。

アプローチの違いは，国・地域がもつ社会背景や社会構造が異なる（産業分布・市場分布等）ものを， 社会全体において将来にわたりどのように合理的な運用が可能かを熟考に熟考を重ねた結果である。各 関係者の役割や実施していることに差はなく, 各地域における固有の社会問題に対して, 端的に行った 結果である。

各国の事情に合わせた法制度の作りこみが，将来にわたる安定的な運用につながる。

キーワード：ASR の処理，EPR（拡大生産者責任），役割分担，使用済み自動車の処理，メーカ責任

\section{1. は じめに}

使用済み自動車の適正処理・リサイクルは, 多くの 国々で重要な課題となっている。とりわけ問題が深刻化 した日本と EUでは, 比較的早い時期に使用済み自動車 のリサイクルの法制度が整備された。日本, EU どちら に抢いても，使用済み自動車の処理に対する責任と役割 を、ユーザ、処理・リサイクル業者, 行政, 製造業者の 4 者が担うという新たな政策を織り込んだ形で制度化が 行われたのである。

日本， EU とも社会問題化した原因の根幹は同じであ ると考えられるが, その対応のアプローチは異なるもの となった。端的にいえば，日本は使用済み自動車が逆有 償に至る要因であった残渣（ASR：Automobile Shredder Residue ${ }^{\dagger}$ ) 等の引き取りをメーカ責任としたのに対 し，欧州は逆有償となった使用済み自動車そのものを引

原稿受付 2015.4.28

* (社) 日本自動車工業会 リサイクル・廃棄物部会 グローバルリサイクル対応分科会 連絡先： ₹ 105-0012 東京都港区芝大門 1-1-30 日本自動車会館 $16 \cdot 17$ 階
き取ることをメーカ責任とした点が大きく異なるのであ る。ただ，いずれの場合でも，そのコストを直接，もし くは間接的にユーザが負担し, 処理はメーカが契約を 行った処理・リサイクル業者へ委託を行うという点では ほぼ同じである。

こうしたアプローチの違いは, 国・地域がもつ社会背 景や経済・社会構造（産業分布・市場分布等）が異なる ことに十分配慮しつつ, 社会全体に扔いて将来にわたり どのように合理的な運用が可能かについて検討を重ねた 結果によるものである。各関係主体の役割や実施内容に 大きな違いはなく, 各国・地域における固有の社会問題 に対して, 的確に対応した結果であると考えられる。各 国の事情に合わせた法制度の構築が, 将来にわたる安定 的な運用につながるものと思われる。

以上のことを念頭に置きつつ, 本稿では日本と EU で 行われている使用済み自動車のリサイクル制度について 比較検討を行い, 使用済み自動車リサイクル制度の異同 を明らかにする。そうすることによって, 日本の使用済

\footnotetext{
†自動車破砕残渣。使用済み自動車から有用部品を取り外した後 破砕し, 金属その他の有価品を分離回収した後に残存する物。使 用済み機械製品等の破砕残椬は SR (Shredder Residue) という
} 
み自動車リサイクル制度の新たなる展開に寄与できるも のと期待している。

\section{2. 制度の成り立ち}

第二次世界大戦後日本や欧州で戦後復興の経済成長が 達成され，1960 年代からは急速なモータリゼーション の普及によって, 短期間に大量の自動車が生産され市場 へ投入された。高度経済成長期に起きたモータリゼー ションは人々の暮らしを経済的に豊かにしたが，その一 方で, 1970 年代に入ると自動車によって環境に与えら れるマイナスの部分が社会問題化した。まず排出ガスに よる都市公害が大きな問題となり，その問題克服が重要 な課題となった。また 1973 年に第一次オイルショック が起きると低燃費化の要望が強まった。こうした問題が 起きるたびに, 自動車メーカはその都度対応してきたわ けである。

さて, 自動車の普及から 10 数年が経過し使用済み自 動車が大量に出るようになると, 使用済み自動車処理 · リサイクルのビジネスも拡大した。自動車にかかわる動 脈経済・静脈経済の双方がより大きな発展を遂げたので ある。だが 1990 年代に入ると人口密度の高い国が多い $\mathrm{EU}$ や日本では, 使用済み自動車処理後の残椬すなわち ASR の埋立処理場の残余容量が逼迫し, 埋立コストが 上昇するようになった。他方, 先進国の経済成長の勢い が衰えると資源相場も下落し，とりわけ鉄スクラップの 価格が低迷する事態が生じた。こうして使用済み自動車 の価值が下がり, とうとう逆有償化する事態が生じた。

以上の事態に対応するため, 日本では解体業者や破砕 業者はASRの金属分をより徹底的に分別し有価部分を 抽出することによって採算改善を図ったが, 埋立コスト の上昇には追いつかず使用済み自動車の逆有償化に歯止 めがかからなかった。その結果, 一部の破砕業者等が ASR を不法投棄するという深刻な社会問題に日本は直

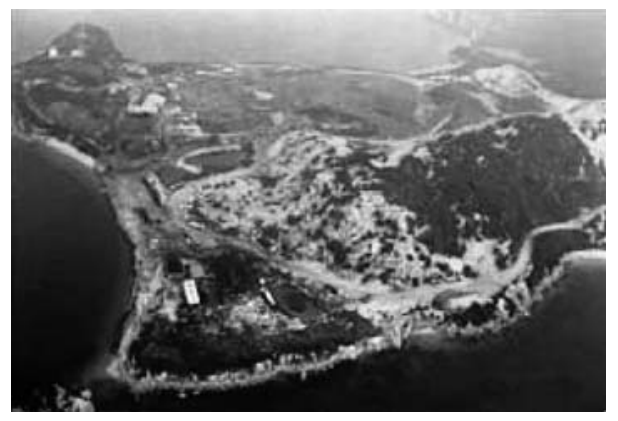

図 11990 年代当時不法投棄が行われた香川県豊島の全 景
面することになったのである（図 1)。加えて，使用済 み自動車そのものの不法投棄も見られるようになった。 そこで日本・EUの行政当局は, 自動車メーカにも使 用済み自動車の処理責任を課す拡大生産者責任, いわゆ るEPR (Extended Producer Responsibility ${ }^{\dagger}$ ) を廃棄物 政策に織り込み, 各々の国・地域に合わせた制度化を行 なった。もとより，EPR といってもその適用の仕方は 一律ではなく，国や地域の特性の差が制度の差となって 現れている点は指摘するに值する。その差に応じて現れ る制度の違いを以下考察することにしょう。

\section{1 国や地域の相違}

\subsection{1 日本}

まず地理的な環境条件についてであるが，日本は島国 であるために，使用中の自動車（使用過程車と呼ぶ）の 国外からの流入，国外への流出が限定的である。もとよ り, 中古車の海外輸出入はあるが, 貿易取引として管理 されている。当局が関知しないままでの使用過程車の国 外流出入は極めて限られている。

次に, 自動車の登録制度が日本では整備されているた め, 車両の捕捉率は高い。車台番号によって一台一台補 足することが可能であり，所有者も㧍扮むね特定できる。

また, 1970 年頃には使用済み自動車処理・リサイク ルの設備の数は整っていたことが大きな特徴としてあげ られる。質の相違はあるにせよ, 解体設備やシュレッ ダー設備がほぼ全国で整っていた。

そして，不法投棄という社会問題に対処することを主 眼として, 使用済み自動車が逆有償になる要因を除去す ベく法制化を行った点も指摘するに值する。その要因と は, 端的にいえば, ASRが最終処分される埋立処理場 の残余容量の逼迫によって ASR の処分費用が高騰化し たことである。その対策として ASR の埋立量を極小化 することを自動車メーカに課し，コストはユーザが負担 するという方法が採られた。

\footnotetext{
製品に対する生産者責任を製品のライフサイクルの使用後段 階まで拡大することであり，政策特徴として，

（1）処理または処分に対する責任（の全面的もしくは部分的） を地方自治体から生産者へ移す

（2）製品設計の際，環境に配慮するよう生産者に動機づける

こととなっている。運用の基本原則は以下の 4 点

(1) 目標設定や目標值 (リサイクル率, リサイクル可能率等)

(2) 利害関係者による協議（責任等役割分担）

(3) 政策および政策立案の透明性（審議会等での議論, 周知活動 等)

(4) 一般市民・関係業者（利害関係者）への情報提供（実績公表 や解体マニュアルの発行等) がある
} 


\subsubsection{EU}

日本と異なり $\mathrm{EU}$ 加盟国は陸続きであり, 使用過程車 の流入流出が極めて多い。EU 加盟国内では, 国境を越 えた自動車の流出入は原則自由であるから, その移動を 当局が関知・管理することは困難である。

加えて, 国によって登録制度に差があるため, $\mathrm{EU}$ 加 盟国内で統一的な管理を行うことが難しいという問題が ある。加盟国内での使用過程車の移動が大きい上, 登録 制度が一律ではないため, 上記のことと相まって, 使用 過程車・使用済み自動車の補足が極めて難しくなってい る。

これも日本と大きく異なる点であるが, 使用済み自動 車の処理・リサイクルの設備等は国により相違が大きい。 国によって使用済み自動車の処理の水準 - 質が著しく異 なるのである。さらに, すべての処理設備を把握できて いる国とできていない国がある点にも触れておかねばな らない。

そして，一般的にGDP の高い国で使用された車が自 国で需要されなくなると, GDP の低い国へ輸出され, そこで最終的に使用済み自動車となる。しかしながら GDP の低い国では使用済み自動車を受け入れる充分な 処理・リサイクル設備が整備されておらず, 使用済み自 動車の処理コストを負担できないユーザが車両の不法投 衰を行っていた。

こうした事態に鑑み，EUではまず自動車メーカが無 償引取を保証する制度が法制化されたのである。

\section{2 地域特性差が制度に与えた結果}

\section{2 .1 日本}

先に, 日本では使用済み自動車の処理・リサイクル設 備は全国的に整備されていたということを述べた。その ような基盤があるからこそ, 既存業者の設備や役割を活 かし, ユーザ, 行政へ役割分担を求め, 自動車メーカ (および輸入業者) が逆有償化の主要因である ASR を 引き取る制度に至ったわけである。

2.2.2 EU

EUにおいては，上に述べたように使用過程車・使用 済み自動車の処理・リサイクル設備の状況が加盟各国で 大きく異なるため, 日本のような制度はとりにくい。そ こで, 市場原理を活かしつつ, 自動車メーカ（および輸 入業者）が使用済み自動車を引き取り, 処理・リサイク ル設備へ資金を投入する義務を担うことになったのであ る。

したがって, 基本的にユーザは市場原理に基づいて使 用済み自動車の引取先を判断することになる。より高く 引き取ってくれる引取先に使用済み自動車を引き渡すこ
とになるのである。

一方, 処理・リサイクル業者は, 自らが処理した量を 自国の政府に報告する義務を負っている。そして各国政 府がリサイクル実績の最終責任を担うのである。これは 日本と決定的に異なる点である。

\section{3. 現 状 分 析}

\section{1 日本と EU の間での運用実態の違い}

\section{1 .1 日本}

使用済み自動車の処理・リサイクルが自動車の登録制 度とリンクしており, 電子システムによって情報（処理 状況）と費用 (含む預託金) 双方がほぼリアルタイムで 管理されている。お拈むね $100 \%$ の使用済み自動車に ついて，情報と費用が把握されている。このことと使用 済み自動車の逆有償化の解消によって, ASR や使用済 み自動車の不法投棄も少なくなった。

3.1 .2 EU

EUにおいては加盟国で登録制度が一律でない上に, 登録制度と使用済み自動車処理の情報がリンクしていな い。このため, 多くの行方不明車が存在している。使用 済み自動車の数さえ正確に捕捉できていないのである。

また，処理実績は，調査票を利用したデー夕収集であ り(年 1 回, 欧州委員会の集計は 3 年ごと), 捕捉率は 低く, 正確な処理の実態の把握が難しい状況である。

\section{2 モニタリング}

既に述べたように，EUでは多くの行方不明車が存在 しており，その数は約 400 万台/年に至るともいわれて いる1”。このことは, EUにおいては使用済み自動車に ついても捕捉率が低いことを意味している。登録制度の 整備された日本と, そうでない $\mathrm{EU}$ との間で使用済み自 動車の捕捉率が異なるのも当然のことといえよう。

2008 年の統計データによると, 約 1,650万台の自動車 が EU 27 力国の市場に投入されている。同年同市場の 保有から抹消された自動車は, 約 1,140万台あるとなっ ている。排出された自動車の内訳は, 使用済み自動車処 理をされたことがわかっている台数は約 630 万台, 中古 車輸出された台数が約 100 万台となっている。残り約 410 万台は同市場から排出されたのはわかっているが, どのようになったかは不明である（図 2)。

使用済み自動車のリサイクル率については, 各国ごと にリサイクル率は集計されている。2006 年リサイクル率 目標 $(85 \%)$ は大半の国が達成されている。EUの置かれ た状況をみると, 2015 年リサイクル率の目標 (95\%)を 達成するためには，たとえば PST (Post Shredder Tech- 


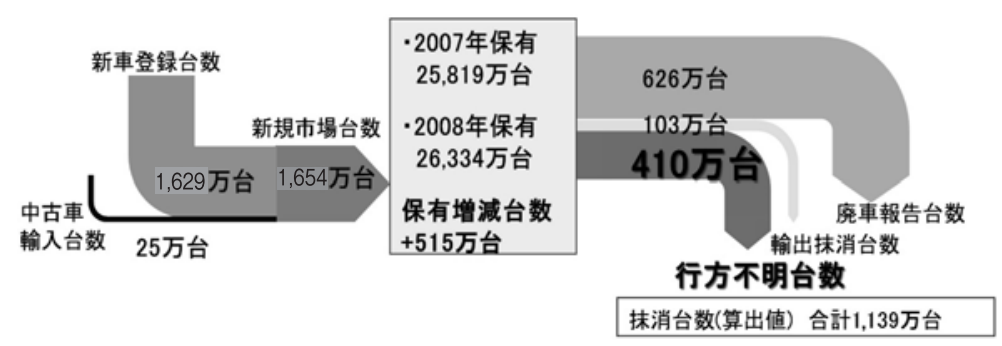

図 2 EU : 27 カ国の自動車全体のフロー (2008 年) ${ }^{2)}$

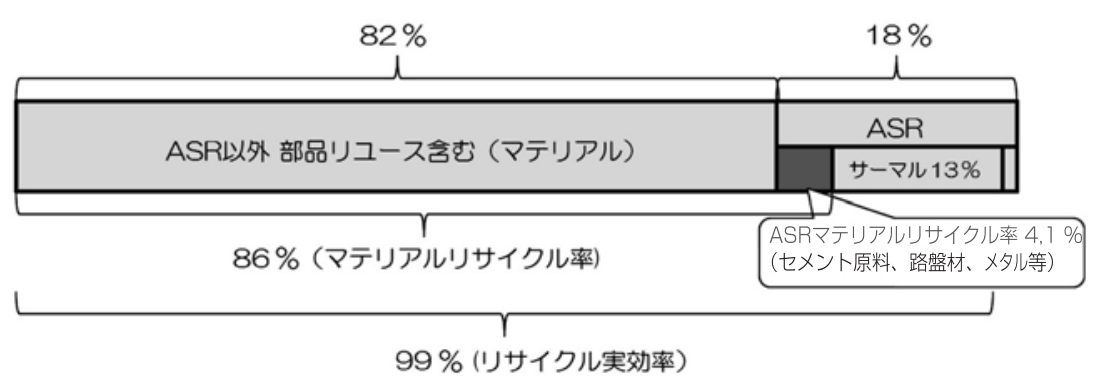

図 3 日本の使用済み自動車のマテリアルリサイクル率とリサイクル実効率（車両全体）

nology ${ }^{\dagger}$ ) 施設等のような, より高度なリサイクル技術 が必要になるものと思われる。ただし，各国ごとにリサ イクルの定義が異なるため, 厳密な意味での相互比較が 困難な状況である。

リサイクルの定義を EU 加盟国間で比較すると, 自国 の産業分布の違いによって異なるところが特徴的である。 たとえばドイツは, メカニカルリサイクル（鉱山埋戻 材）やフィードストックリサイクル（高炉還元剤）を認 めている。一方鉱業がない国は, マテリアルリサイクル を行い新たな産業を模索しているが, 経済合理性を確保 するに至ってはいないのが現状である。

日本と EUではリサイクル率を算出する対象物が異な り，したがってリサイクル率の定義にも相違が生じる。 だが、日本の目標リサイクル率は EU のリサイクル率の 定義に照らしても $95 \%$ 相当であり, 全体でみると,リ サイクル率目標值で日本と EU の間で本質的な差はない ものと考えられる。

\section{3 日本のマテリアルリサイクル率}

次に, 日本における使用済み自動車のリサイクルの中 身, 特にマテリアルリサイクルの実態をみてみると, 解 体業者や破砕業者により車両全体重量の $82 \%$ のマテリ

†使用済み自動車を破砕後に出た ASR をより分別し有用物を分 離回収する技術
アルリサイクル（リユースを含む）が行われており， シュレッダーダスト分である車両全体重量の $18 \%$ のう ち $23 \%$ がマテリアルリサイクルされている(これは, 車両全体重量の $4.1 \%$ に相当する)。都合, 車両全体重 量の $86 \%$ のマテリアルリサイクルが行われている計算 となる (図 3 )。

\section{$3.4 \mathrm{EU}$ のガラス・樹脂のリサイクル}

$\mathrm{EU}$ のマテリアルリサイクルで一部特徵的な点は, ガ ラス・樹脂のリサイクルである。EUで法制化された当初 (2003 年) は EU ELV指令 ANNEX I でこうした品目 のリサイクルが義務化されていだ”。しかしながら, 2009 年 EU 委員会や, SEPA (Scottish Environment Protection Agency) 等が, 事前取外しに経済合理性がないと 報告した。

実際, 経済合理性の観点から, 一部事業者の取り組み を除き,こうした品目のリサイクルは行われていない。 市場ベースで実行できないからである。現在ガラス・樹 脂のリサイクルを行っている業者は, オランダ, フラン ス等の一部の国の事業者に限られている。

ドアガラスは, 叨き割り採取し，フロントガラスのよ うな合わせガラスは, 専用のカッター工具を使い自動車 から取り外し, ガラスのみを入れるコンテナに分別し回

サ使用済み自動車（End of Life Vehicle）のこと 


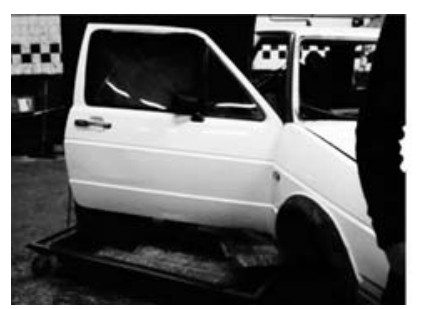

図 4 Maresia Auto Recycling (オランダ)

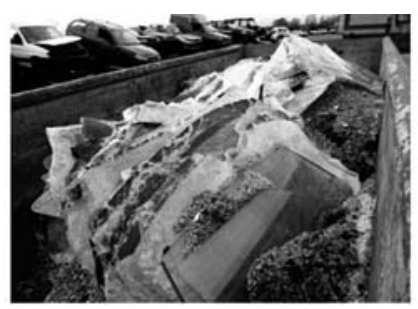

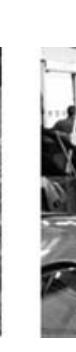

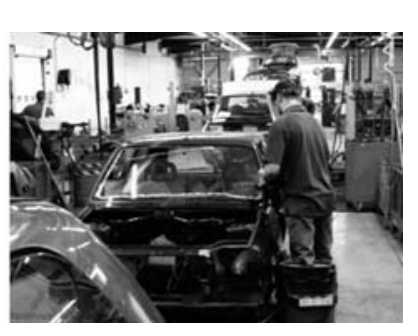

INDRA（フランス）
収している（図 4)。

オランダは ARN (Automobile Recycling Nederland ${ }^{\dagger}$ ) が新車購入者から, 使用済み自動車処理にかかるコスト を基金として徴収している（45 ユーロ/台（2014 年 2 月 現在)）。その基金の一部を用いてガラス樹脂リサイクル を行っているのである。これに対しフランスは, PST 技術を使い, ASR 中の樹脂の選別とリサイクルを実施 している。広域回収と家電, 容器包装等全セクターの廃 プラスチックを受け入れることによって経済合理性を確 保している。ただ, これは日本のような一般廃棄物と産 業廃棄物という法律上の区別がないからこそ可能になる ことなのである。

\section{5 ステークホルダの役割分担}

次に, コスト負担者・実施主体者・リサイクル目標達 成義務者等に関する日欧の相違をみる。

3.5 .1 日本

日本では,リサイクルコストの負担を, 逆有償化する 要因の品目のみユーザが直接負担することになっている。 そしてその費用をもとに自動車メーカはリサイクル・適 正処理を実施している。それ以外の廃車全体は解体業者 や破砕業者により, 市場原理に基ついて適正なリサイク ルが行われている。ここでの適正なリサイクルとは, 中 古部品・リビルト部品としての利用や原材料化を意味す る。

\subsubsection{EU}

EUでは，ユーザが間接的に負担している。ここで 「間接的」とは, 市場取引において使用済み自動車が逆 有償になった時にそのコストを車両売価に内部化するこ とを意味する。しかし，このコスト額の明細は不明であ る。消費者に転嫁されているかどうか, どのように転嫁 されているかなどもわからない。

既に述べたように,リサイクルの目標值の達成義務は,

\footnotetext{
†オランダ自動車リサイクル協会。同協会は 1995 年 1 月よりオ ランダ国内のリサイクルシステムの管理・運営等, 実務面を 担っている
}

日本においては自動車メーカが負い, EUにおいては最 終義務は国が負うことになっている。ただし，日本では ASR, フロンガス, エアバッグの 3 品目のみのリサイ クル率目標值である。

\section{4. 現状の課 題}

\section{1 日欧の課題}

次に, 使用済み自動車の適正処理・リサイクルについ ての現在の課題を明らかにし, 将来に向けての新しい適 正処理・リサイクルのあり方を展望する。

4.1 .1 日本

第 1 にあげられるのがリサイクルの質の向上である。 確かに, 使用済自動車の再資源化等に関する法律（自動 車リサイクル法) 施行によってリサイクル率が向上し, $95 \%$ という目標率は達成されている。また, 高いリサ イクル率達成によって, ASRの最終処分量削減にも成 功した。ただ, リサイクルの中身については, 廃棄物の ヒエラルキーサに従って, サーマルリサイクルからより 質の高いマテリアルリサイクルへの転換を推進する必要 性は認識されている。もとより, より質の高いリサイク ルを行うとすると, ほとんどの場合コストの上昇が避け られない。そのため, リサイクルの質を向上させる取り 組みについては, 現状の実施状況を踏まえつつ, リサイ クルコストのユーザ負担に配慮しながら, どのように進 めることができるか検討しなければならない。

第 2 は次世代車および素材の多様化への対応である。 次世代自動車は従来型自動車と較べてパーツ・素材等の 仕様・構成が大きく異なる。次世代自動車で使用される 素材の多様化, たとえば炭素繊維強化プラスチック (CFRP : Carbon-Fiber Reinforced Plastic ${ }^{\dagger \dagger}$ ) 等の素材

円発生抑制(発生回避), リユース, マテリアルリサイクル, サーマルリサイクル (熱回収), 適正処分という処理の順序を指 す

林炭素繊維に樹脂を混ぜて作った複合素材。軽くて高強度, 高 弾性率をもつ。自動車用途では燃料電池車の水素タンクに使用 されている。ゴルフのシャフトや航空機の機体が有名 
に対応するには，従来とは異なった形の DfE（Design for Environment, 環境配慮設計) (たとえば, 解体・リ サイクルのしやすさ等) を行う必要がある。自動車メー カはこの問題を解決するために, 関係各主体と共同・連 携しながら，技術開発の推進を現在試行中である。

第 3 はリサイクルにかかわる社会的コストの低減とい う課題である。自動車リサイクルの社会的コストの低減 に向け, 自動車メーカは ASR, フロンガス, エアバッ グの 3 品目の処理コストのさらなる低減を推進していく 予定である。さらに, 費用低減の究極の目的として, 使 用済み自動車を有償化する方向へのシステム転換が目指 されるべきである。これはただ自動車メーカのみででき ることではなく, 関係各主体の一層の努力が必要である が, 最も重要なのは国の役割であり, 国の主導による政 策転換が必要であろう。たとえば ASR に資源価值が出 てくるのはどのような条件の下においてなのか, 社会 経済構造を転換することも考え合わせた上で，国はよく 関係者と議論を重ねるべきである。

4.1.2 EU（「フィットネスチェック（政策評価）最終 報告書」(2014.7.2 公表) より)

まず使用済み自動車リサイクルのリサイクル率の目標 達成についてであるが, EU 加盟国では, 2006 年目標 （リサイクル率 $85 \%$ ）は捄むね達成した。これによっ て廃棄物のヒエラルキーに従った質の高いリサイクルが 進むとともに，不法投棄も減少した。ただ，現状の処 理・リサイクルの状況が続いた場合, 2015 年目標（リ サイクル率 $95 \%$ ）達成は容易ではなく，目標達成のた めには多くの国において PST 等新たな技術・工夫が必 要である。PST 等新たな技術を活用した使用済み自動 車処理セクター等による雇用機会の創出も工夫の一つと いわれている。

次に，モニタリングの精度の向上も大きな課題である。 使用済み自動車と中古車の明確な区分をつけ, 公認業者 が使用済み自動車を扱い正確な報告を行うことにより, 統計の信頼性と比較可能性を確保することが課題とされ ている。登録を抹消する際に, 破壊証明書が必ずしも提 出されていない運用が原因とされている。そのため非公 認の解体業者による使用済み自動車の回収および処理と, 中古車と偽った使用済み自動車の輸出入等が行える環境 下にある。対策として最終ユーザが使用済み自動車を公 認業者へ引き渡すために，インセンティブを付ける提案 もある。

最後に，正確な使用済み自動車が把握できたとしても， 各国ごとにリサイクルについての定義が異なることも問 題である。リサイクルの定義の不統一のために, リサイ クル率の信頼性や比較可能性に関して問題が指摘されて
いる。EUは使用済み自動車のリサイクルについて共通 で透明性の高い定義を作るべきだろう。

\section{2 自動車メーカの役割}

次世代車をはじめ今後自動車に求められるさまざまな 要求 (低燃費化·安全性強化等) にも対応しつつ, 使用 済み自動車の環境負荷低減に向け新技術や新素材の採用 を自動車メーカは積極的に推進していく必要がある。そ の際により質の高い DfE を行い, それと同時に解体業 者や破砕業者等への安全性確保やユーザ負担の低減につ なげていく努力を継続していかなければならない。

たとえば現在二次電池や CFRP の効率的な処理・リ サイクルについては, 自動車メーカで研究が行われてい る最中である。また, 燃料電池に用いられているプラチ ナの効率的な国内循環を働きかけることも自動車メーカ にとって大きな課題である。

\section{5.おわりに}

以上, 日本と EUの自動車リサイクル制度を比較検討 してきたが, 双方とも各々の社会問題に対し，ある一定 の効果を上げてきたことが理解できる。異なった社会背 景をもちながらも, 双方ともに一定の成果が上げられた のは, 各々の社会背景に適合した政策に基づく制度に よって的確なアプローチがとられたからであると考えら れる。

日本は自動車リサイクル制度と登録制度とのリンクを うまく行い, また関係業者の処理実施状況を把握する電 子システムを構築し, モニタリングの制度を高めること ができた。この高いモニタリング制度により，自動車 メーカにASR, フロンガス, エアバッグの 3 品目を確 実に引き取らせ, リサイクル率目標值を達成させること で, 最終処分量の削減が可能になったのである。あわせ 不法投棄問題も解消できた。

一方, 欧州では市場原理の下, 自動車メーカに使用済 み自動車を引き取らせた。またスクラップ金属相場の上 昇も手伝い, 自動車リサイクル法が不法投棄の解消に寄 与してきた。加盟各国, リサイクルの内容に多少の相違 はあるものの, 総じて質の高いリサイクルが行なわれて いる。

今後さらにこの政策を発展させ, 安定的に運用するに は, 関係各主体は,さしあたり現状の細かい課題・問題 の対策を講じていくべきである。自動車メーカは新技術 や新素材を既存の設備で確実な処理ができるようにして いくことが求められる。一方, 長期的な視野で新たな政 策を検討することも必要で, より社会コストを抑え, よ 
り継続性のある効率的な循環型社会構築に向けた貢献に

むけ, 自動車メーカが次に何をすべきか求められている。 現在の使用済み自動車処理にかかわる関係者の役割を 十分に果たした上で，より実効性のある制度へ昇華させ ることはもちろんのことである。だが, 現在の関係業者 のみで経済合理性をもたそうとすることには限界もある。 日本では廃棄物は, 一般廃棄物と産業廃棄物をはじめ, 廃棄物の由来により区分がされている。たとえば樹脂の リサイクルを行う際, ASR 由来の樹脂と SR 由来の樹 脂と混合し再生樹脂を作る際, 別々の施設からの集約が 必要となり, 効率が低下する。このため, 法制度がもっ ている課題と新たな再生樹脂を製造する事業者の創造, そして再生樹脂を使った製品需要の喚起等, 新たな枠組
みを検討することが必要であり，また，さまざまな産業 との融合を考える新たな政策に貢献していくことを期待 している。

\section{参 考文 献}

1) EU : EX-post Evaluation of Five Waste Stream Directives, SWD (2014) 209 final (2014)

2 ) 欧州委員会 気候変動総局：EUの中古車市場に関する 報告書（和訳）（2008）

3) EU : Directive 2000/53/EC of the European Parliament and of the Council of 18 September 2000 on End-of Life Vehicles (2000)

\title{
Comparison of European and Japanese ELV Recycling Systems
}

\author{
Toshifumi Imada \\ Japan Automobile Manufacturers Association, Inc. \\ Recycling \& Waste Reduction Subcommittee \\ Global Recycling Working Group \\ (Jidosha Kaikan 1-30, Shiba Daimon 1-Chome, Minato-ku,Tokyo 105-0012 Japan)
}

\begin{abstract}
Both the European and Japanese ELV recycling systems incorporate the policy of sharing roles and responsibilities for the recycling of ELVs among the four types of stakeholders, i. e. vehicle users, recycling operators, the government and automakers. While Europe and Japan originally confronted similar public issues regarding ELV disposal, the two regions selected somewhat different approaches. Japan made dealing with ASR, the most costly and technically difficult step in the entire ELV recycling process, the responsibility of automakers while Europe made it the responsibility of automakers to deal with every aspect of ELVs, inclusive of ASR. In both regions, the users are asked to pay for the recycling costs either directly or indirectly, and the automakers then hire their contractors to do the actual work of dismantling, recycling and disposal.

The different approaches taken by Europe and Japan stem from careful deliberations over the design and development of a practical system that can be operated and publicly accepted over a long period of time in each social setup, having its own unique industry distribution and market makeup. In both Europe and Japan, the stakeholders have performed their roles in an effort to address the specific public issues existing in each region. For the sustained operation of the ELV recycling system additional efforts will need to be made, especially in improving the relevant laws and regulations to better match the conditions existing in Europe and Japan.
\end{abstract}

Keywords : ASR disposal, EPR (Extended Producer Responsibility), role sharing, disposal of end-of-life vehicles, producer responsibility 